\title{
Evaluation of nutritional characteristics and consumers' acceptance of gluten-free sweet biscuits made from rice-based pregelatinized composite flours containing orange pomace and soy protein isolate
}

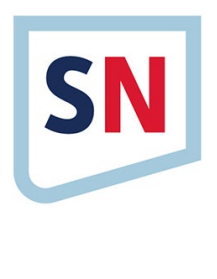

\author{
Caroline Alves Cayres ${ }^{1}$ (i) . José Luis Ramírez Ascheri ${ }^{2} \cdot$ Maria Antonieta Peixoto Gimenes Couto $^{3}$
}

Received: 31 August 2020 / Accepted: 12 January 2021 / Published online: 23 January 2021

(c) The Author(s) $2021 \quad$ OPEN

\begin{abstract}
Gluten-free bakery products are usually deficient in dietary fiber and inferior sources of protein. Studies that have assessed sensory characterization of products prepared with orange pomace are scarce. This study evaluated the employment of $30 \%$ of rice-based pregelatinized composite flours (containing 15,25 or $35 \%$ orange pomace blended with $5 \%$ soy protein isolate) on gluten-free biscuits. The target was the investigation of the nutritional profile and consumer's acceptance of three short dough sweet biscuit samples. Thermoplastic extrusion was an efficient unit operation for the elaboration of a new gluten-free ingredient in which a by-product rich in total dietary fiber and a component with a high level of protein were employed. All pregelatinized composite flours in this study can be labeled as protein sources and can be claimed as high in total dietary fiber content, as well as two biscuit samples that can be labeled as total dietary fiber source. Also, all pregelatinized composite flours and biscuits presented low moisture and water activity, being microbiologically stable to room temperature $\left(25 \pm 2{ }^{\circ} \mathrm{C}\right)$. Complementarily, the results of the microbiological evaluations [(coagulase-positive Staphylococcus, thermotolerant coliform $\left(45^{\circ} \mathrm{C}\right.$ ) and Salmonella sp. (absence in $25 \mathrm{~g}$ )] of the biscuits and their comparison with the Brazilian microbiological standards legislation attested their safety. Concerning the sensory analysis, adults' results showed that the flavor attribute might be responsible for increasing the overall impression score of a sample. In contrast, children's results showed that they did not distinguish $(p \geq 0.05)$ two of three samples of biscuits analyzed.
\end{abstract}

Keywords Dietary fiber - Extrusion cooking · Industrial by-product - Physicochemical characterization · Protein ingredient $\cdot$ Sensory evaluation

\section{Introduction}

Biscuits are one of the most popular bakery items consumed by nearly everyone, appealing to children, teenagers, adults, and elderly ones. These products are convenient, ready-to-eat, inexpensive and affordable snacks, being able to present a great variety of flavors, prepared through baking into a low moisture content $(<5 \%)$, which gives them a long shelf-life. They serve as a source of energy for many people [1]. Attempts are being made to improve biscuits' nutritive value by modifying their nutritive composition. This objective is very often achieved by increasing the ratios of different types of dietary fiber and protein in an elementary formulation. The goal is to serve healthier and more functional food market demand [2].

Caroline Alves Cayres, caroline.a.cayres@gmail.com; José Luis Ramírez Ascheri, jose.ascheri@embrapa.br; Maria Antonieta Peixoto Gimenes Couto, gimenes@eq.ufrj.br | ${ }^{1}$ Graduate Program in Engineering of Chemical and Biochemical Processes at School of Chemistry, Technology Center, Federal University of Rio de Janeiro, Avenida Athos da Silveira Ramos 149, Ilha do Fundão, Rio de Janeiro, RJ 21941-909, Brazil. ' Embrapa Agroindústria de Alimentos, Avenida das Américas 29501, Guaratiba, Rio de Janeiro, RJ 23020-470, Brazil. ${ }^{3}$ Technology Center, School of Chemistry, Federal University of Rio de Janeiro, Avenida Athos da Silveira Ramos, 149, Ilha do Fundão, Rio de Janeiro, RJ 21941-909, Brazil. 
Gluten and related proteins found in grains contribute to a cluster of diseases, not limited to celiac disease [3]. Underneath the umbrella of gluten-related disorders, there are also people with wheat allergy, non-celiac gluten sensitivity, dermatitis herpetiformis and gluten ataxia [4]. For them, gluten could also be considered a "toxin" based upon its mechanism of action in the small bowel and perhaps even in the central nervous system [5]. Besides the people needing to follow a gluten-free diet for health reasons, a new segment of consumers has arisen who consume gluten-free products as a lifestyle choice [4]. However, gluten-free bakery products are generally deficient in dietary fiber due to the use of pure refined flour and/or starch as primary raw materials for their preparation [6]. Gluten-free products are also usually inferior sources of protein [7]. The importance to simultaneously improve both the quality and the nutritional profile of gluten-free products has been stimulating researchers to investigate new ingredients and technologies to be applied in glutenfree bakery products [8]. Rice flour is the most suitable source of starch for gluten-free bakery applications due to its bland taste, white color, digestibility, and hypoallergenic properties [6]. Furthermore, it is entirely feasible to employ rice flour in short dough biscuit formulation. The addition of soy proteins to rice flour improves the amino acid balance of the new ingredient since legume and cereal proteins are complemented in the essential amino acids lysine and methionine. The rice flour obtained by thermoplastic extrusion presents increased cold viscosity, and reduced peak viscosity and tendency to retrograde as the amount of gelatinized starch is higher than the rice flour without any thermal treatment [9].

As the nutritional value has also become an essential aspect of gluten-free foodstuffs [10], the addition of fruit pomace to biscuits is one of the possible approaches that could be adopted to increase their dietary fiber and minerals contents. For instance, orange pomace, an abundant agricultural by-product, is a fibrous residue of orange left over after the extraction of the juice. Brazil, the world's largest producer of oranges, produced more than seven thousands of tonnes of orange pomace in 2019 [11], which represents $50 \%$ of the mass of oranges employed in Brazilian orange juice industry. Orange pomace is an excellent source of dietary fiber, considering that $83 \%$ of orange pomace's total dietary fiber is the insoluble fraction and its soluble fraction is mostly composed of pectin [12], besides being rich in minerals [13]. So, orange pomace could be used as an excellent source of nutritionally enhancing and eco-friendly compounds [14]. Using orange waste by-products as a raw material in the food industry will bring lots of health promotion like preventing obesity, overweight and diabetes due to its fiber content [15], as this component impacts all aspects of gut physiology
[1]. Hence, there are two strong reasons to rescue orange pomace into the food industry: improve the nutritional quality of food products to which it can be added and reduce the disposal of waste in the environment concomitantly. Also, the protein quality improvement of gluten-free bakery products with sources of protein-rich ingredients seems to be unavoidable. Soy protein isolate is one of soy protein products with high protein content, without anti-nutritional factors such as trypsin inhibitor, lipoxygenase, and urease [2]. Moreover, soy protein presents a health effect on calcium metabolism and lowering cholesterol [16].

Thermoplastic extrusion is a method in which starch and/or protein are transformed into plastic polymers by adding little water, and they are cooked with a high degree of mechanical energy. Functional ingredients which have an unpleasant taste alone can be mixed with other components into a unique food item through thermoplastic extrusion. Also, extrusion can reduce anti-nutritional compounds, promoting safer and more nutritious foods. Extrusion improves protein digestibility via denaturation, while total dietary fiber can be affected in different ways by this process [8]. Regarding dietary fiber, Huang and $\mathrm{Ma}$ [17] investigated the effect of extrusion processing (barrel temperatures: $115-135^{\circ} \mathrm{C}$; feed moistures $10-18 \%$ ) on the physicochemical properties of extruded orange pomace. They found a redistribution of insoluble dietary fiber to soluble dietary fiber in the extrusion cooking, in which the soluble dietary fiber fraction of the extruded orange pomace was significantly $(p<0.05)$ higher than that of unextruded pomace. Hence, the extruded orange pomace flour may contribute to heightening the insoluble/soluble dietary fiber ratio in food formulations. The thermoplastic extrusion can be an efficient unit operation for processing a by-product rich in dietary fibers and an ingredient with a high level of protein, through the incorporation of these two components into a starch-rich matrix.

Consumer acceptance is an indicator for prospective purchase intentions and intake as well [18]. Nevertheless, current research in extruded ingredients is focused mainly on reformulation strategies rather than sensory aspects, and this gap needs to be addressed [14]. Studies that have assessed sensory characterization of products prepared with orange pomace flour are scarce. From the literature review, there is scanty information about any attempt to produce gluten-free biscuits fortified with dietary fiber and protein by the employment of orange pomace flour and soy protein isolate to the biscuit dough. Therefore, the present study aimed at the physicochemical characterization of pregelatinized composite flours (PCFs), formulated with white rice flour, orange pomace flour, and soy protein isolate. The goal was to develop nutritionally enriched gluten-free biscuits in terms of dietary fiber, minerals, and 
protein by the incorporation of PCFs as a source of the abovementioned compounds. The biscuits also went for microbiological analysis (coagulase-positive Staphylococcus, thermotolerant coliform $\left(45^{\circ} \mathrm{C}\right)$ and Salmonella sp.) to ensure their safety for consumption. Finally, adults' and children's acceptance of these biscuits was assessed.

\section{Material and methods}

\subsection{Material}

White rice was purchased in the local market in the city of Rio de Janeiro (Brazil). The by-product (consisted of flavedo, albedo, and seeds) remained after orange (Citrus sinensis variety Osbeck) juicing was collected from an industrial extractor Otto 1800 (Organização Industrial Centenário Ltda; Limeira, Brazil) at the food processing industry Bora Bora Comércio e Indústria Ltda (Rio de Janeiro, Brazil). Soy protein isolate utilized originates from Marsul Proteínas LTDA (Montenegro, Brazil).

The ingredients used in the preparation of the biscuits were: pregelatinized composite flour (PCF) (prepared as described in Sect. 2.1.2) and whey powder (Laticínios Porto Alegre, Ponte Nova, Brazil). Corn starch, vegetal shortening, refined sugar, brown sugar, egg, soy lecithin, ammonium bicarbonate, sodium bicarbonate, and salt were purchased in local markets in the city of Rio de Janeiro (Brazil).

\subsubsection{Preprocessing of raw material}

White rice flour was produced through milling this cereal on the knife and hammer granulator mill (TREU S.A.; Rio de Janeiro, Brazil), with $1 \mathrm{~mm}$ sieves.

The by-product of orange juicing was ground on a multiprocessor Cadence Mix for You MPR853 right after collecting (JCS Brasil Eletrodomésticos SA; Balneário Piçarras, Brazil), dispersed on trays, and dehydrated in a turboelectric oven FTT 390G (Tedesco; Caxias do Sul, Brazil) at $60^{\circ} \mathrm{C}$ for $5 \mathrm{~h}$. After dehydration, the by-product was milled in a disc mill LM3600 (Perten Instruments AB; Huddinge, Sweden), set to aperture 6 . This product will henceforth be called orange pomace flour.

\subsubsection{Formulation, conditioning, and extrusion of composite flours}

Three composite flours were elaborated by mixing the raw materials: white rice flour (composition: $10.83 \%$ moisture, $6.37 \%$ protein and $82.80 \%$ carbohydrates; not detectable contents of lipid, ash, and total dietary fiber), orange pomace flour (composition: $2.35 \%$ moisture, $4.76 \%$ protein, $1.82 \%$ lipid, $3.77 \%$ ash, $47.16 \%$ total dietary fiber and $40.14 \%$ carbohydrates) and soy protein isolate (composition: $5.02 \%$ moisture, $85.15 \%$ protein, $0.72 \%$ lipid, $4.30 \%$ ash and $4.81 \%$ carbohydrates). These ingredients were mixed on a powder homogenizer Chopin (Tripette \& Renaud; Villeneuve la Garenne, France) and subsequently conditioned. The proportion of raw materials in the composite flour, the moisture conditioning, and the temperature in the third zone of the extruder were described in Table 1. For each variable, the levels were established according to preliminary experiments (unpublished results).

Conditioning moisture was adjusted by the conditioning of $2 \mathrm{~kg}$ composite flour. The determination of moisture was carried out, in duplicate, using AACC Method 44-16.01 [19]. Distilled water was slowly added to the sample in the process of homogenization in blender HMT (Guangzhou Panyu Jianye; Guangzhou, China). After the addition of water, the samples were stored into sealed polyethylene bags, in refrigeration, for $17 \mathrm{~h}$.

The extrusion was conducted using a single-screw extruder DO-CORDER Brabender (Brabender; Duisburg, Germany). The extrusion profile was: feed section speed: 40 rpm; shear rate: 5:1; screw speed: 180 rpm; feed section temperature: $80^{\circ} \mathrm{C}$; compression section temperature $100^{\circ} \mathrm{C}$; circular die diameter: $3 \mathrm{~mm}$.

The extrudate was dehydrated in a fan oven Macanuda Hauber DMS-G (Macanuda Hauber; Joinville, Brazil) at $60{ }^{\circ} \mathrm{C}$ for $4 \mathrm{~h}$ and subsequently milled on a disc mill LM3600 (Perten Instruments AB; Huddinge, Sweden), set to aperture 0 , and, afterward, on a hammer mill LM3100 (Perten Instruments AB; Huddinge, Sweden), with $0.8 \mathrm{~mm}$ sieves. The obtained product will henceforth be called as pregelatinized composite flour (PCF).

\subsection{Assessment of physical characteristics of pregelatinized composite flours}

Two hundred $\mathrm{g}$ of PCF were sieved for $10 \mathrm{~min}$ in the sieve shaker ROTAP RX-29-10 (WS Tyler; Ohio, USA), utilizing steel mesh sieves, which frame is $8^{\prime \prime} \times 2^{\prime \prime}$, with $212 \mu \mathrm{m}$ and $106 \mu \mathrm{m}$ screen sieve sizes. The material of particle size inferior to $212 \mu \mathrm{m}$ [20] was used to standardize particle sizes. The samples were packed into polyethylene bags, sealed, labeled, and stored in a cool $\left(25 \pm 2^{\circ} \mathrm{C}\right)$, dry place until the analyses were carried out.

\subsubsection{Hydration properties}

Water solubility index (WSI) and water absorption index (WAI) of PCFs were determined according to the methodology described by Anderson et al. [21], in quadruplicate. WSI indicates the amount of sample that is solubilized in water at $30^{\circ} \mathrm{C}$ relative to the initial sample after shaking 


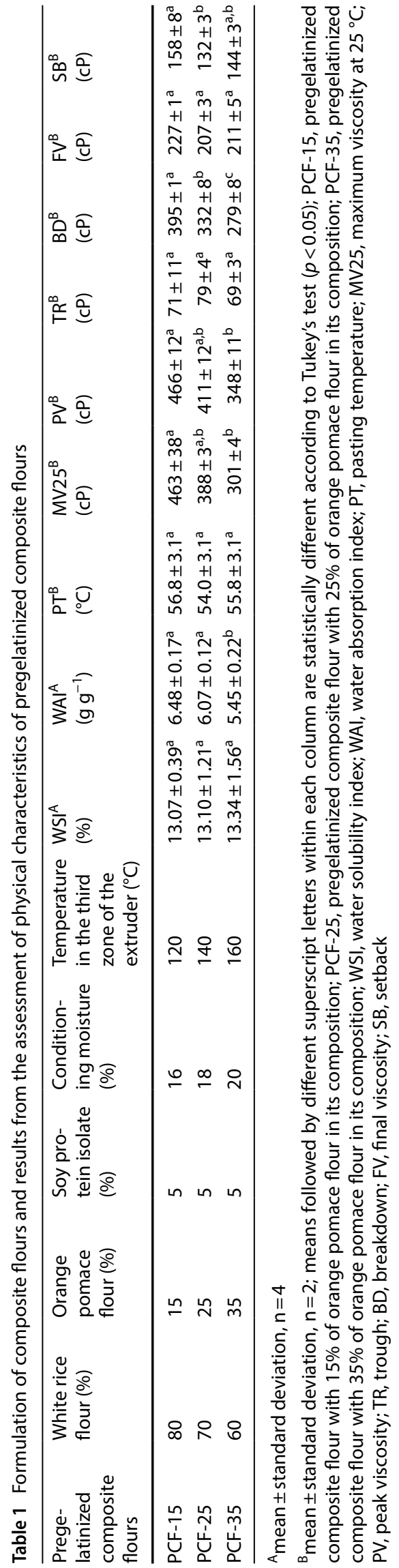

and centrifuging. In comparison, WAI reports the amount of water absorbed at $30^{\circ} \mathrm{C}$ related to the sample that did not solubilize under shaking and centrifugation.

\subsubsection{Pasting properties}

The viscosity of PCFs was determined, in an aqueous medium, under heating and stirring, using the equipment Rapid Visco Analyser (RVA) (Newport Scientific; Warriewood, Australia), according to AACC Method 76-21.01 [22], with modifications. The flour was initially stirred during $10 \mathrm{~s}$, at the initial temperature of $25^{\circ} \mathrm{C}$ and $960 \mathrm{rpm}$. The remainder of the procedure, which lasted $20 \mathrm{~min}$, was conducted at $160 \mathrm{rpm}$. The initial temperature was held for $2 \mathrm{~min}$ and gradually raised, heating to $95^{\circ} \mathrm{C}$, at a constant rate of $14^{\circ} \mathrm{C} \mathrm{min}^{-1}$. Then, the temperature was held constant for $3 \mathrm{~min}$ and cooled to $25^{\circ} \mathrm{C}$, at a constant rate of $14^{\circ} \mathrm{C} \mathrm{min}{ }^{-1}$, which was held during the last $5 \mathrm{~min}$ of the analysis.

The readings from the paste curve generated were: pasting temperature (PT), maximum viscosity at $25^{\circ} \mathrm{C}$ (MV25), peak viscosity (PV), trough (TR), breakdown (BD), final viscosity (FV), and setback (SB), obtained through the register carried out by the software Thermocline (Newport Scientific; Warriewood, Australia). The measurements were conducted in duplicate.

\subsection{Short dough sweet biscuit production}

Preliminary baking tests were made to adjust the biscuit formula. Gluten-free flour was elaborated by mixing corn starch and PCF in a fixed proportion of 7:3. This proportion was chosen according to the study of Ostermann-Porcel et al. [23], in which the gluten-free cookies prepared with flour containing $30 \%$ of okara flour, in substitution to manioc flour, were preferred by the consumers. The biscuit formula, on a gluten-free flour weight basis, was: $35 \%$ water, $30 \%$ vegetal shortening, $20 \%$ refined sugar, $20 \%$ brown sugar, $5 \%$ egg, $2 \%$ soy lecithin, $2 \%$ ammonium bicarbonate, $2 \%$ whey powder, $1 \%$ sodium bicarbonate, and $1 \%$ salt. To produce the biscuit, gluten-free flour, refined sugar, brown sugar, soy lecithin, ammonium bicarbonate, whey powder, sodium bicarbonate, and salt were mixed during 2 min at medium speed in a planetary mixer (HMT, China). Vegetal shortening and egg were added to this mixture and mixed for $5 \mathrm{~min}$. Water was added little by little to the above cream and mixed for $3 \mathrm{~min}$ at medium speed to get the biscuit dough. After mixing, biscuit dough was sheeted manually to a thickness of $4 \mathrm{~mm}$, cut using a knife, to form rectangles of $7 \mathrm{~cm} \times 1 \mathrm{~cm}$. Cut dough was transferred to stainless trays and then baked in an electric oven (Suggar, China) at $200^{\circ} \mathrm{C}$ for $15 \mathrm{~min}$. Finally, biscuits were kept at room temperature $\left(25 \pm 2^{\circ} \mathrm{C}\right)$ for $1 \mathrm{~h}$ before analyses. 


\subsection{Assessment of physicochemical characteristics of pregelatinized composite flours and biscuits}

\subsubsection{Proximate composition}

The proximate composition was carried out using Association of Official Analytical Chemists methods [24], in duplicate measurements: moisture content (Method 925.09), total nitrogen (Method 2001.11, a conversion factor of 5.75 was used to convert total nitrogen to protein content), lipid content (Method 945.38), ash content (Method 923.03), and total dietary fiber (Method 985.29). Carbohydrates were determined by difference.

\subsubsection{Mineral composition}

The quantification of minerals sodium $(\mathrm{Na})$, potassium $(\mathrm{K})$, magnesium $(\mathrm{Mg})$, calcium $(\mathrm{Ca})$, phosphorus $(\mathrm{P})$, manganese $(\mathrm{Mn})$, iron (Fe), zinc ( $\mathrm{Zn})$ and copper $(\mathrm{Cu})$ was determined by Inductively Coupled Plasma Optical Emission Spectrometry (ICP-OES) (Optima 2100DV, Perkin Elmer, USA) after complete digestion of the sample in nitric and perchloric acids, following the Methods 975.03 and 990.08 of Association of Official Analytical Chemists methods [24], in duplicate measurements.

\subsubsection{Water activity}

Water activity $\left(25^{\circ} \mathrm{C}\right)$ was measured in AquaLab LITE (Decagon; Pullman, USA), in duplicate measurements.

\subsection{Microbiological analysis of biscuits}

The microbiological evaluations (coagulase-positive Staphylococcus, thermotolerant coliform $\left(45^{\circ} \mathrm{C}\right)$ and Salmonella sp. (absence in $25 \mathrm{~g}$ ) were performed according to the American Public Health Association [25]. These species were selected following the Brazilian legislation for biscuits [26].

\subsection{Sensory evaluation}

Tests were carried out at the School of Chemistry of the Federal University of Rio de Janeiro (UFRJ) and Colégio de Aplicação (UFRJ) and were approved by Ethics Committee (CAAE 0027.0.313.000-11). All adult participants and those responsible for the children received written information about the study before giving their informed consent. This procedure was adopted to avoid risks (mainly food allergy or intolerance) to the participants, following the rules of the Ethics Committee. There was no incentive for attending the test.

The three biscuit samples (approximately $7 \mathrm{~g}$ each) were served to the consumers on monadic presentation, in random and balanced order [27]. Samples were coded with three-digit numbers and served to consumers in white plastic plates. Water and crackers were provided for palate cleansing.

\subsubsection{Adults}

2.6.1.1 Participants A total of 151 consumers [28, 29] participated in the test. Participants ( 86 women and 65 men, in which $66 \%$ were aged between 18 and 24 years old, $28 \%$ between 25 and 35 years old, 3\% between 36 and 50 years old, and 3\% more than 51 years old) were recruited from the staff and the students present in the university environment during the test.

2.6.1.2 Affective test An acceptance test was carried out to evaluate appearance, aroma, flavor, crunchiness, and overall impression, using a 9-cm hedonic unstructured scale anchored at $0.5 \mathrm{~cm}$ on both ends with "dislike extremely" at the left and "like extremely" at the right (Fig. 1) [30]. The position on the line scale indicated by consumers was converted to a number between 0 (leftmost position) and 9 (rightmost position).

2.6.1.3 Purchase intention Just after the acceptance test, participants were asked about how much they were likely to purchase the biscuit that gave rise to the coded sample. Purchase intention was assessed using a 5-point structured scale ranging from "would certainly buy" to "would certainly not buy" [30].

(a)

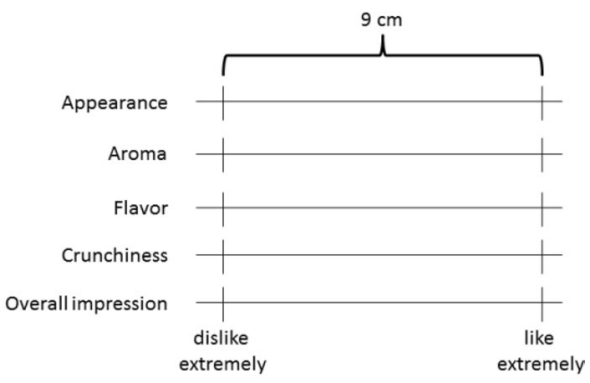

(b)

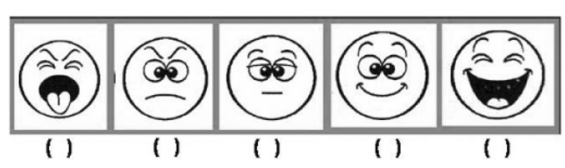

Fig. 1 Scales used in affective tests. a adults: 9-cm hedonic unstructured scale, b children: 5-point facial hedonic scale 


\subsubsection{Children}

2.6.2.1 Participants A total of 111 consumers [28, 29] participated in the test. Participants (54 girls and 57 boys, in which $20 \%$ were aged 8 years old, $31 \% 9$ years old, $36 \%$ 10 years old and $14 \% 11$ years old) were recruited from the students present in the elementary school environment during the test, with the prior permission of those responsible.

2.6.2.2 Affective test An acceptance test was carried out to evaluate the overall impression, using a 5-point facial hedonic scale (Fig. 1). Values from 1 to 5 are assigned to each facial expression of the hedonic scale presented to children [30].

\subsection{Statistical analyses}

Differences between the mean values for the analyses made on PCFs and biscuits were assessed by the analysis of variance (ANOVA; $p<0.05$ ) and followed by the Tukey test $(p<0.05$, only when significant differences were observed in ANOVA). Correlations between hydration properties and pasting properties of pregelatinized composite flours and physicochemical characteristics of pregelatinized composite flours and biscuits were done by Pearson correlation coefficients. A p-value $<0.05$ (2-sided) was considered as statistically significant. For the aforementioned statistical analyses, it was employed Statistica software 11.0 for Windows (StatSoft Inc.; Tulsa, USA).

\section{Results and discussion}

\subsection{Physical characteristics of pregelatinized composite flours}

\subsubsection{Hydration properties}

WSI is an adequate index to measure the intensity of the extrusion conditions; likewise, the transformation that occurs in starch molecules [31]. This index still discloses the degradation of total dietary fiber (TDF) components submitted to severe processing conditions, which entails the production of compounds having a low molecular weight [17]. Furthermore, lower shear rates occur during the thermoplastic extrusion in which higher conditioning moistures are employed [32]. Commonly, the increase in the barrel temperature manages to the rise in WSI values, which result in more water-soluble compounds due to the increment in damaged starch granules [31, 32]. As can be seen in Table 1, the higher the conditioning moisture, the higher the temperature in the third zone of the extruder.
This combination of these parameters of the thermoplastic extrusion process was responsible for the WSI values of all PCFs, which did not differ statistically $(p \geq 0.05)$ (Table 1$)$. It is possible to conclude that although the concentrations of orange pomace flour are different in each of the PCFs, the degree of degradation suffered by this ingredient's TDF, as well as the relative proportion of damaged starch granules was the same in all PCFs produced. Soy protein isolate and TDF, along with conditioning moisture, may have caused a damping effect on shear rate.

The damaged starch performs a higher capacity for holding water at room temperature and swelling in contrast to the native starch, increasing WAI [33]. Considering that the native starch does not absorb water since the extruded starch absorbs water quickly and form a gel at 30 ${ }^{\circ} \mathrm{C}$ or lower temperature [31], WAl estimates the amount of water absorbed by the starch. It can be used as an index for the gelatinization degree of the sample [21]. The lowest WAI value presented for PCF-35 (Table 1) is probably due to its most moderate content of starch. Similar results were reported by Altan et al. [34], on barley extrudates containing different concentrations of tomato and grape pomace, and by Cortez et al. [35], on two types of blue corn extrudates combined with orange pomace. The result of the present study could indicate that in composite flours whose proportions of rice flour are less than 70\%, TDF and proteins present in the formulation protect the starch from gelatinization.

\subsubsection{Pasting properties}

Pasting properties are considered as one of the most critical indices in the evaluation of starch-rich ingredients and raw materials. The viscosity of a paste mainly relies on the degree of gelatinization of the starch granules and the rate of molecular breakdown [36].

Higher values of MV25 indicates a more significant starch breakdown, which forms a three-dimensional network at $25^{\circ} \mathrm{C}$ as a result of more hydrophilic sites of the sheared starch molecules exposed to water; therefore, indicating high shearing during extrusion [36]. It is possible to infer that MV25 parallels to WAI $(R=0.997, p<0.05)$. Hence, the differences $(p<0.05)$ observed between the MV25 values presented for PCF-15 and PCF-35 (Table 1) can be explained for the same reasons abovementioned for WAI (Sect. 3.1.1).

In the course of the heating cycle of the pasting viscosity profile, $\mathrm{PV}$ is the maximum viscosity presented by the sample. This property coordinates to the quality of the final product because PV indicates the maximum swelling of the starch granules due to the sample waterbinding capacity [37]. The highest PV value presented for PCF-15 (Table 1) could be assigned to its most top 
content of starch, and also more starch granules with a high swelling capacity.

Amylose leaching out and alignment are the results of further starch granules disruption due to high temperature and mechanical shear stress to which the sample is submitted during the holding period of the viscosity test. Generally, this period is followed by a breakdown in viscosity [37]. As BD is the difference between PV and $M V 25$, it is expected that high values of $B D$ are associated with high PV. This implication can be observed in Table 1. Moreover, it is conceivable to find another phenomenon occurring in parallel. As suggested by Kim and Walker [38], lipids may inhibit water transfer into the granules due to a film cover, which increases the hydrophobicity of starch. The observed highest BD (Table 1) related to the lowest lipids content in PCF-15 (Table 2) supports this explanation.

The difference between FV and TR represents SB. The viscosity of the sample presents a variation during its reassociation at the stage of RVA cooling, which reveals the degree of starch retrogradation. Accordingly, SB ties into the texture properties of the final product [39]. Lower SB values $(p<0.05)$ (Table 1$)$ are related to higher protein and lipid contents $(p<0.05)$ (Table 2$)$. These two components could have surrounded the starch granules and may have caused a protective effect against starch retrogradation and syneresis.

\subsection{Physicochemical characteristics of pregelatinized composite flours and biscuits}

\subsubsection{Proximate composition}

The nutrient content (Table 2) of the pregelatinized white rice flour fortified with different proportions of orange pomace flour and soy protein isolate significantly increased in comparison to the white rice flour. There was an increase of at least $56 \%$ of protein content in PCFs when compared to that of white rice flour, in addition to the enrichment in ash and TDF contents (Table 2), which were not even detected in white rice flour. Therefore, fortification of orange pomace flour, as well as soy protein isolate, could be used in the production of PCFs enhanced in protein, ash, and TDF contents.

According to the CODEX Alimentarius [40], the results for the protein content (Table 2) show that PCF-25 can be labeled as a protein source ingredient/food because it contains at least $5 \mathrm{~g}$ of protein per $100 \mathrm{~g}$. Similarly, PCF15 and PCF-35 can be labeled as high in protein content considering that they contain more than $10 \mathrm{~g}$ of protein

Table 2 Composition, energy value and water activity of pregelatinized composite flours and biscuits

\begin{tabular}{|c|c|c|c|c|c|c|}
\hline \multirow[t]{2}{*}{ Components } & \multicolumn{3}{|c|}{ Pregelatinized composite flours } & \multicolumn{3}{|l|}{ Biscuits } \\
\hline & PCF-15 & PCF-25 & PCF-35 & B-15 & B-25 & B-35 \\
\hline Moisture (g/100 g) & $7.86 \pm 0.04^{\mathrm{a}}$ & $7.47 \pm 0.16^{\mathrm{a}}$ & $7.61 \pm 0.01^{\mathrm{a}}$ & $3.99 \pm 0.01^{\mathrm{B}}$ & $4.53 \pm 0.04^{\mathrm{A}}$ & $3.43 \pm 0.06^{C}$ \\
\hline Protein $(\mathrm{g} / 100 \mathrm{~g})$ & $10.18 \pm 0.04^{\mathrm{a}}$ & $9.95 \pm 0.00^{b}$ & $10.00 \pm 0.04^{\mathrm{a}, \mathrm{b}}$ & $2.47 \pm 0.00^{A}$ & $2.36 \pm 0.08^{\mathrm{A}}$ & $2.70 \pm 0.08^{A}$ \\
\hline Lipid (g/100 g) & $0.19 \pm 0.01^{c}$ & $0.64 \pm 0.04^{\mathrm{a}}$ & $0.36 \pm 0.01^{\mathrm{b}}$ & $18.71 \pm 0.15^{\mathrm{A}}$ & $18.35 \pm 0.10^{\mathrm{B}}$ & $18.28 \pm 0.14^{B}$ \\
\hline Ash (g/100 g) & $1.20 \pm 0.01^{c}$ & $1.53 \pm 0.01^{b}$ & $1.69 \pm 0.03^{\mathrm{a}}$ & $1.44 \pm 0.03^{\mathrm{A}}$ & $1.43 \pm 0.01^{\mathrm{A}}$ & $1.51 \pm 0.03^{\mathrm{A}}$ \\
\hline Sodium (Na) (mg/100 g) & $67.88 \pm 0.96^{\mathrm{a}}$ & $68.09 \pm 0.15^{\mathrm{a}}$ & $66.16 \pm 0.19^{\mathrm{a}}$ & $435.60 \pm 4.78^{A}$ & $401.29 \pm 6.65^{A}$ & $408.97 \pm 4.56^{A}$ \\
\hline Potassium (K) (mg/100 g) & $258.84 \pm 2.18^{c}$ & $359.76 \pm 2.42^{b}$ & $414.91 \pm 0.28^{\mathrm{a}}$ & $98.32 \pm 1.10^{B}$ & $115.50 \pm 2.15^{\mathrm{A}}$ & $123.03 \pm 2.81^{\mathrm{A}}$ \\
\hline Magnesium (Mg) (mg/100 g) & $56.07 \pm 0.60^{b}$ & $60.08 \pm 0.04^{\mathrm{a}}$ & $60.04 \pm 0.27^{\mathrm{a}}$ & $16.49 \pm 0.14^{\mathrm{A}}$ & $16.92 \pm 0.53^{A}$ & $17.10 \pm 0.36^{A}$ \\
\hline Calcium (Ca) (mg/100 g) & $111.35 \pm 2.96^{c}$ & $180.11 \pm 4.54^{b}$ & $223.43 \pm 4.23^{\mathrm{a}}$ & $48.90 \pm 1.41^{B}$ & $57.99 \pm 0.69^{B}$ & $68.84 \pm 1.71^{\mathrm{A}}$ \\
\hline Phosphorus (P) (mg/100 g) & $186.60 \pm 2.50^{\mathrm{a}}$ & $183.97 \pm 1.12^{\mathrm{a}}$ & $176.36 \pm 0.43^{a}$ & $77.49 \pm 0.83^{\mathrm{A}}$ & $75.81 \pm 1.60^{\mathrm{A}}$ & $73.42 \pm 0.72^{\mathrm{A}}$ \\
\hline Manganese $(\mathrm{Mn})(\mathrm{mg} / 100 \mathrm{~g})$ & $0.98 \pm 0.01^{\mathrm{a}}$ & $0.95 \pm 0.02^{\mathrm{b}}$ & $0.91 \pm 0.02^{c}$ & $0.28 \pm 0.01^{A}$ & $0.27 \pm 0.01^{A}$ & $0.27 \pm 0.01^{\mathrm{A}}$ \\
\hline Iron $(\mathrm{Fe})(\mathrm{mg} / 100 \mathrm{~g})$ & $1.42 \pm 0.01^{b}$ & $1.48 \pm 0.01^{\mathrm{b}}$ & $1.64 \pm 0.01^{\mathrm{a}}$ & $1.81 \pm 0.05^{\mathrm{A}}$ & $1.62 \pm 0.11^{\mathrm{A}}$ & $1.94 \pm 0.01^{\mathrm{A}}$ \\
\hline Zinc (Zn) (mg/100 g) & $1.64 \pm 0.07^{\mathrm{a}}$ & $1.43 \pm 0.02^{b}$ & $1.33 \pm 0.03^{b}$ & $0.39 \pm 0.01^{\mathrm{B}}$ & $0.44 \pm 0.01^{A}$ & $0.38 \pm 0.01^{\mathrm{B}}$ \\
\hline Cooper (Cu) (mg/100 g) & $0.29 \pm 0.01^{b}$ & $0.29 \pm 0.01^{\mathrm{b}}$ & $0.31 \pm 0.01^{\mathrm{a}}$ & $0.10 \pm 0.01^{A}$ & $0.09 \pm 0.01^{A}$ & $0.07 \pm 0.01^{A}$ \\
\hline Total dietary fiber ( $\mathrm{g} / 100 \mathrm{~g}$ ) & $7.51 \pm 0.02^{c}$ & $11.81 \pm 0.01^{\mathrm{b}}$ & $13.84 \pm 0.04^{\mathrm{a}}$ & $1.97 \pm 0.02^{C}$ & $3.59 \pm 0.01^{B}$ & $5.47 \pm 0.03^{\mathrm{A}}$ \\
\hline Carbohydrates $(\mathrm{g} / 100 \mathrm{~g})$ & $73.06 \pm 0.02^{\mathrm{a}}$ & $68.60 \pm 0.02^{b}$ & $66.50 \pm 0.04^{b}$ & $71.42 \pm 0.01^{\mathrm{A}}$ & $69.74 \pm 0.02^{A}$ & $68.61 \pm 0.02^{A}$ \\
\hline Energy value (kcal/100 g) & $334.76 \pm 0.05^{a}$ & $319.96 \pm 0.83^{b}$ & $309.27 \pm 0.21^{c}$ & $464.00 \pm 0.88^{A}$ & $453.57 \pm 0.41^{B}$ & $449.76 \pm 0.37^{C}$ \\
\hline Water activity $\left(25^{\circ} \mathrm{C}\right)$ & $0.370 \pm 0.004^{a}$ & $0.341 \pm 0.007^{\mathrm{a}, \mathrm{b}}$ & $0.330 \pm 0.001^{b}$ & $0.410 \pm 0.000^{A}$ & $0.272 \pm 0.016^{B}$ & $0.223 \pm 0.004^{C}$ \\
\hline
\end{tabular}

mean \pm standard deviation, $\mathrm{n}=2$; means followed by different superscript lower case within each row are statistically different according to Tukey's test $(p<0.05)$; means followed by different superscript capital letter within each row are statistically different according to Tukey's test $(p<0.05)$; PCF-15 = pregelatinized composite flour with $15 \%$ of orange pomace flour in its composition; PCF- $25=$ pregelatinized composite flour with $25 \%$ of orange pomace flour in its composition; PCF-35= pregelatinized composite flour with $35 \%$ of orange pomace flour in its composition; B-15 = biscuit formulated with PCF-15; B-25 = biscuit formulated with PCF-25; B-35= biscuit formulated with PCF-35 
per $100 \mathrm{~g}$. A key ingredient to achieve, on average, $10 \%$ of protein content in PCFs was the use of soy protein isolate, even if in a smaller amount (5\%) in the formulation of composite flours.

Furthermore, all PCFs can be claimed as high in TDF content (Table 2) because of containing more than $6 \mathrm{~g}$ of TDF per $100 \mathrm{~g}$, while B-25 and B-35 can be claimed as a TDF source because they contain more than $3 \mathrm{~g}$ of TDF per $100 \mathrm{~g}$, according to the CODEX Alimentarius [40]. The enrichment in TDF content is due to the use of orange pomace flour, which is mostly comprised of celluloses, hemicelluloses, and pectin [41]. In their study, Huang et al. [42] showed that thermoplastic extrusion is a novel strategy for developing orange pomace extrudate with enhanced hypoglycemic, hypocholesterolemic, and fermentative capacities. The reason is due to this functional ingredient exhibited stronger effects than did orange pomace flour in retarding the rate of in vitro glucose diffusion, delaying the rate of glucose absorption, inhibiting the a-amylase activity, binding cholesterol or bile acid capacities, and increasing the total short-chain fatty acids production.

Since the energy value (Table 2 ) is calculated by the sum of each energy source (protein $-4 \mathrm{kcal} / \mathrm{g}$, lipid-9 $\mathrm{kcal} / \mathrm{g}$, and carbohydrates-4 $\mathrm{kcal} / \mathrm{g}$ ), it is expected that the amount of calories provided by each biscuit formulation will be different if these components are presented in higher or lower concentrations. Also, it is observed in Table 2 that the energy value of each biscuit is inversely proportional to its TDF content. This result comes from the formulation of the PCFs (Table 1), where the higher the amount of orange pomace, the lower the amount of white rice flour, and consequently, the less is the available carbohydrates for energy conversion.

Finally, one way to assure that the broad population receives adequate amounts of protein and TDF in the diet is to fortify foodstuffs that would not commonly be correlated with these fortifications. Some examples are foods often eaten as snacks or at breakfast, such as biscuits, consumed by adults and children. For instance, Arribas et al. [43] presented a gluten-free snack-like extruded product with increased levels of protein and dietary fiber, employing pea and carob as enriching ingredients. Also, Morales et al. [44] showed that extrusion promoted an increase in soluble fiber in some gluten-free lentil-based flour formulations, fiber-enriched with corn or apple fibers. Developing and commercializing tempting protein- and TDF-enriched ingredients/ foods is a way by which the food scientists and industry can support consumers in meeting their nutritional needs.

\subsubsection{Mineral composition}

White rice flour, which is part of the composition of PCFs, and corn starch have no detectable contents of ash/minerals. Both of them are typically employed in gluten-free bakery product formulation. Hence, orange pomace flour and soy protein isolate contributed to the enrichment in macro- and microminerals to PCFs and, consequently, to biscuits (Table 2).

Potassium was the most abundant mineral in all PCFs, followed by phosphorus and calcium (Table 2). The addition of PCFs in food products would then increase the amount of the minerals mentioned above. PFC-25 and PCF-35 can be claimed as calcium sources (Table 2), according to the CODEX Alimentarius [40], because they contain more than $150 \mathrm{mg}$ of calcium per $100 \mathrm{~g}$.

It should be noted that one serving $(30 \mathrm{~g})$ of biscuits (Table 2 ) provides, on average, approximately $6 \%$ of the Nutrient Reference Values (NRVs) of iron and copper, each, for children aged between 7 to 10-year-old [45] (representing the children consumers' age group in the present study). All PCFs can be claimed as a copper source (Table 2), according to the CODEX Alimentarius [40], because they contain more than $0.135 \mathrm{mg}$ of copper per $100 \mathrm{~g}$.

It is essential to highlight that one serving $(30 \mathrm{~g})$ of biscuits (Table 2) provides, on average, 3.84\%, 3.62\% and $3.30 \%$ of the NRVs for adults of iron, manganese, and phosphorus, respectively [45]. All PCFs can be claimed as high in manganese content (Table 2), according to the CODEX Alimentarius [40], because they contain more than $0.90 \mathrm{mg}$ of manganese per $100 \mathrm{~g}$. Also, all PCFs can be claimed as a phosphorus source (Table 2), according to the CODEX Alimentarius [40], because they contain more than $105 \mathrm{mg}$ of phosphorus per $100 \mathrm{~g}$.

Additionally, all PFCs can be claimed as a magnesium source (Table 2) according to the CODEX Alimentarius [40] because they contain more than $46.5 \mathrm{mg}$ of magnesium per $100 \mathrm{~g}$.

Considering the intake of $30 \mathrm{~g}$ ( 1 serving) a day of biscuits, sodium intake would be around $125 \mathrm{mg}$ (Table 2), corresponding to $6.25 \%$ of the intake level not to exceed (2,000 mg/day) [46].

\subsubsection{Water activity}

All PCFs and biscuits presented water acitivity $\left(A_{w}\right)$ lower than 0.6 (Table 2); hence, they are enclosed in the category of microbiologically stable foods [47]. Foods that present $A_{w}$ varying from 0.40 and 0.70 must be stored in packs that prevent moisture uptake or loss [48], and do not need refrigerated storage. 
It is observed, both in PCFs and biscuits, that $A_{w}$ is inversely proportional to the content of TDF (Table 2 ) $(\mathrm{R}=0.997, p<0.05$ for PCFs and $\mathrm{R}=0.952, p<0.05$ for biscuits). TDF possesses excellent properties of water absorption and swelling power, which cause high water retention [49], and a subsequent decrease in $A_{w}$.

\subsection{Microbiological analysis of biscuits}

Microbial spoilage is known as the most critical factor affecting the safety and shelf-life of food products prepared with fruits [50], and, consequently, to those that are produced with their by-products.

The results of the microbiological analysis of the biscuits and their comparison with the microbiological standards (Table 3 ) allow the characterization of the products as microbiologically adequate since the values for all microorganism counts are under Brazilian legislation [26]. Therefore, the biscuits can be considered safe for consumption, which indicates that good manufacturing practices have been adopted throughout the entire production chain (manufacture of orange pomace flour, PCFs, and biscuits).

\subsection{Sensory evaluation}

\subsubsection{Adults}

The sensory profile presented in Table 4 demonstrates that appearance and aroma did not show any significant difference $(p \geq 0.05)$ between the three samples of biscuits analyzed (Fig. 2). The flavor of sample B-15 is reported as the preferred one $(p<0.05)$, while the crunchiness of samples B-15 and B-35 achieved the best score.

Santos et al. [51], in a study where gluten-free chocolate biscuits were prepared with cassava starch and orange albedo flour, the biscuits obtained acceptance means ranging from 5 (neither like nor dislike) to 8 (like very much), using a 9-point structured scale. In a study reported by Santos et al. [52], in which chocolate biscuits were prepared with partial replacement of wheat flour
Table 4 Acceptance means for affective tests carried out with adults and children

\begin{tabular}{llll}
\hline Acceptance & \multicolumn{2}{l}{ Biscuits } & \\
\cline { 2 - 4 } & B-15 & B-25 & B-35 \\
\hline Appearance & $4.7^{\mathrm{a}}$ & $4.5^{\mathrm{a}}$ & $4.6^{\mathrm{a}}$ \\
Aroma & $5.0^{\mathrm{a}}$ & $4.8^{\mathrm{a}}$ & $5.0^{\mathrm{a}}$ \\
Flavor & $6.2^{\mathrm{a}}$ & $4.9^{\mathrm{b}}$ & $5.0^{\mathrm{b}}$ \\
Crunchiness & $7.2^{\mathrm{a}}$ & $6.1^{\mathrm{b}}$ & $6.9^{\mathrm{a}}$ \\
Overall impression (adults) & $6.5^{\mathrm{a}}$ & $5.0^{\mathrm{b}}$ & $5.3^{\mathrm{b}}$ \\
Overall impression (children) & $4.0^{\mathrm{A}}$ & $3.9^{\mathrm{A}}$ & $3.6^{\mathrm{B}}$ \\
\hline
\end{tabular}

Means followed by different superscript lower case within each row are statistically different according to Tukey's test $(p<0.05)$, using a 9-cm hedonic unstructured scale from "dislike extremely" to "like extremely". Means followed by different superscript capital letter within each row are statistically different according to Tukey's test $(p<0.05)$, using a 5 -point facial hedonic scale; $\mathrm{B}-15=$ biscuit formulated with pregelatinized composite flour with $15 \%$ of orange pomace flour in its composition; B-25=biscuit formulated with pregelatinized composite flour with $25 \%$ of orange pomace flour in its composition; B-35 = biscuit formulated with pregelatinized composite flour with $35 \%$ of orange pomace flour in its composition

with sour cassava starch and orange albedo flour, the means for all the sensory attributes evaluated (appearance, aroma, flavor, texture and overall impression) were between 5.0 and 7.3, on a 9-point structured scale. These results correspond to the hedonic terms "neither like nor dislike" and "like moderately". Except for the appearance attribute, which obtained means of less than 5.0, the present work got similar scores of the studies mentioned above.

Probably because it reached the best acceptance mean in the flavor attribute, sample B-15 obtained the highest overall impression score, being indirectly preferred among the three samples analyzed. The flavor is more critical than crunchiness for these products. Flavor means may have been lower in samples B-25 and $B-35$ due to the higher amount of orange pomace flour in their formulations, compared to B-15 $(p<0.05)$, as it is an ingredient that consumers are not used to.

Table 3 Microbiological analysis of biscuits

\begin{tabular}{lllll}
\hline Micro-organisms & Biscuits & \multicolumn{2}{c}{ Brazilian legislation $^{\text {a }}$} \\
\cline { 2 - 4 } & B-15 & B-25 & B-35 & \multicolumn{1}{c}{$10 \mathrm{MPN} / \mathrm{g}$} \\
\hline Thermotolerant coliforms (MPN/g) & $<3$ & $<3$ & $<3$ & $5 \times 10^{2} \mathrm{CFU} / \mathrm{g}$ \\
Coagulase-positive Staphylococcus (CFU/g) & $<1 \times 10^{1}$ & $<1 \times 10^{1}$ & $<1 \times 10^{1}$ & Absence in $25 \mathrm{~g}$ \\
Salmonella sp./25 g & Absent in $25 \mathrm{~g}$ & Absent in $25 \mathrm{~g}$ & Absent in $25 \mathrm{~g}$ & \\
\hline
\end{tabular}

MPN most probable number, CFU colony-forming unit

${ }^{a}$ Brazil (2001); B-15 = biscuit formulated with pregelatinized composite flour with $15 \%$ of orange pomace flour in its composition; B-25 $=$ biscuit formulated with pregelatinized composite flour with $25 \%$ of orange pomace flour in its composition; B-35=biscuit formulated with pregelatinized composite flour with $35 \%$ of orange pomace flour in its composition 


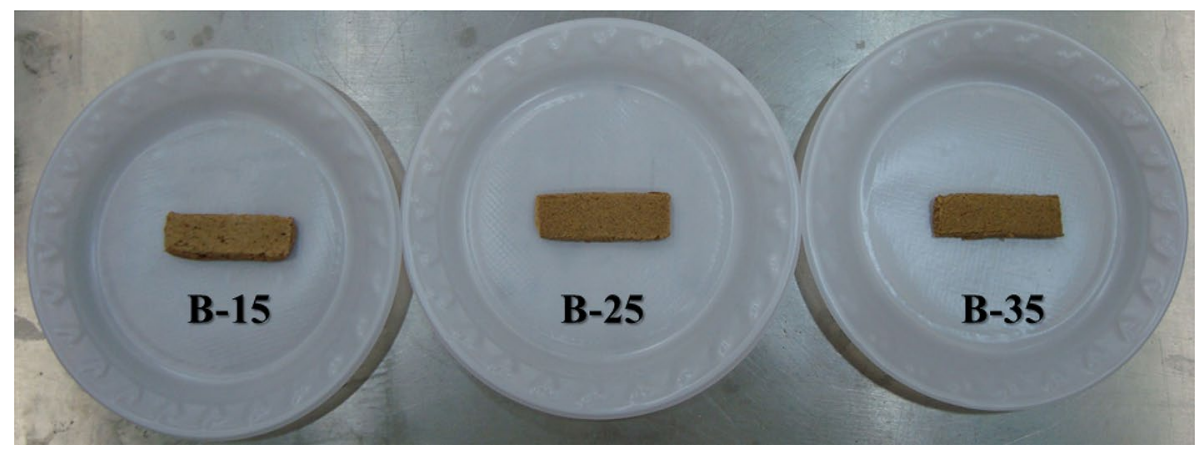

Fig. 2 Biscuit samples. B-15=biscuit formulated with pregelatinized composite flour with $15 \%$ of orange pomace flour in its composition; $\mathrm{B}-25=$ biscuit formulated with pregelatinized com- posite flour with $25 \%$ of orange pomace flour in its composition; B-35 = biscuit formulated with pregelatinized composite flour with $35 \%$ of orange pomace flour in its composition

the lowest mean $(p<0.05)$ presented by sample B-25 in the crunchiness attribute (Table 4 ).

\subsubsection{Children}

Means presented in Table 4 reveal that there was no significant difference in acceptance $(p \geq 0.05)$ between samples B-15 and B-25 and also that these samples were indirectly preferred in this assessment. From this outcome, it is suggested that B- 25 should be the biscuit offered to children, given that its nutrient content is better than the $B-15$ one, as $\mathrm{B}-25$ presented less lipids and more potassium, zinc and TDF (Table 2).

In the study presented by Seo et al. [53], in which five different types of foods containing wild blueberry powder were prepared for sensory testing, children liked and wanted to consume the cookies more when compared to beverages, ice pops, and/or gummies. Their results corroborate the idea that biscuits can be appropriate food
Fig. 3 Purchase intention of biscuits. B-15 = biscuit formulated with pregelatinized composite flour with $15 \%$ of orange pomace flour in its composition; B-25 = biscuit formulated with pregelatinized composite flour with $25 \%$ of orange pomace flour in its composition; B-35 = biscuit formulated with pregelatinized composite flour with $35 \%$ of orange pomace flour in its composition

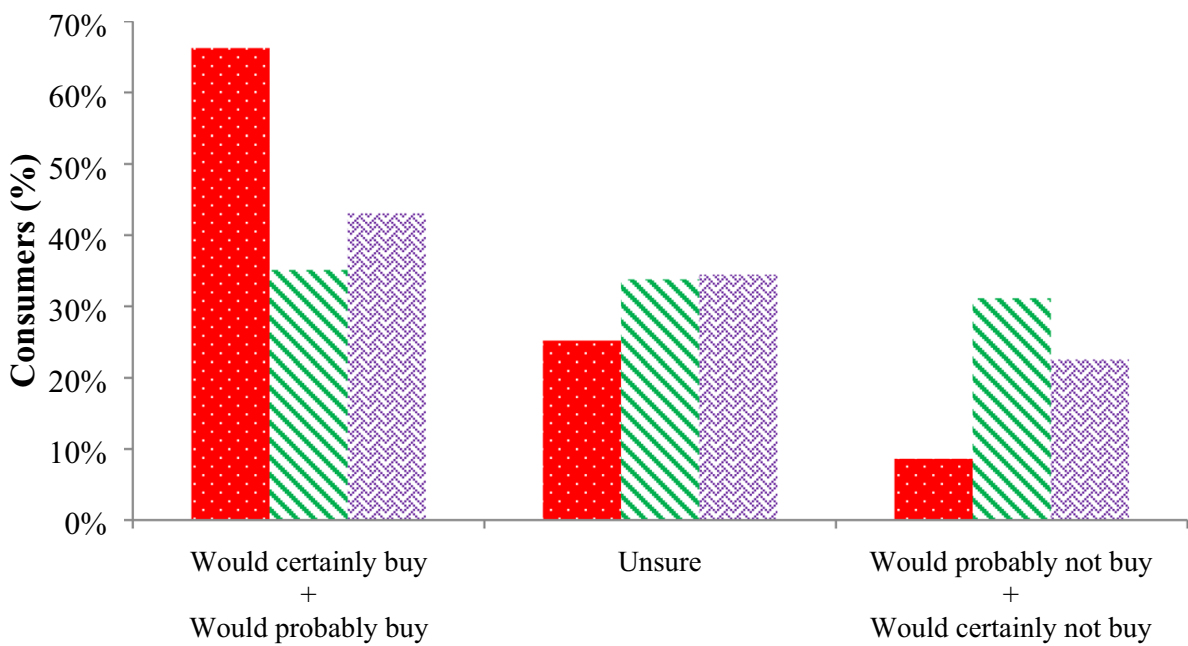

B-15 $、 \mathrm{~B}-25 \times \mathrm{B}-35$ 
products to be enriched with fruit pomace powders, to achieve better means of sensory acceptance within children.

\section{Conclusions}

The present study delineated a strategy of the utilization of a TDF-rich food industry by-product (orange pomace) and a protein-rich ingredient (soy protein isolate) through the employment of thermoplastic extrusion to produce a new gluten-free ingredient.

The results showed that fortification of gluten-free biscuits with pregelatinized composite flour (PCF, elaborated with white rice flour, orange pomace flour, and soy protein isolate) can be used to produce TDF source gluten-free biscuits. Concerning the sensory analysis, adults' results demonstrated that the flavor attribute might be responsible for increasing the overall impression score of a sample. In contrast, children's results showed that they did not distinguish ( $p \geq 0.05$ ) two of three samples of gluten-free biscuits analyzed. Indirectly, adults indicated that the preferred gluten-free biscuit formulation was the one containing the PCF with $15 \%$ of orange pomace flour. In comparison, children presented no significant difference in acceptance $(p \geq 0.05)$ for biscuit in which it was employed the PCF with $25 \%$ of orange pomace flour as well.

As future perspectives for research, the following studies are suggested: i) new ways of presenting biscuits, since the lowest means were given for the appearance attribute in sensory analysis, ii) adding natural aromas to improve consumer acceptance, and iii) sensory evaluation of biscuits using the Check-All-That-Apply (CATA) method and to correlate the descriptive profile given by CATA with consumer hedonic responses to identify the drivers of liking and disliking.

Funding This study was financed in part by the Coordenação de Aperfeiçoamento de Pessoal de Nível Superior-Brasil (CAPES) Finance Code 001. The authors thank CAPES for the master's scholarship and FAPERJ for the productivity grant.

\section{Compliance with ethical standards}

Conflict of interest The author declares that they have no conflict of interest.

Open Access This article is licensed under a Creative Commons Attribution 4.0 International License, which permits use, sharing, adaptation, distribution and reproduction in any medium or format, as long as you give appropriate credit to the original author(s) and the source, provide a link to the Creative Commons licence, and indicate if changes were made. The images or other third party material in this article are included in the article's Creative Commons licence, unless indicated otherwise in a credit line to the material. If material is not included in the article's Creative Commons licence and your intended use is not permitted by statutory regulation or exceeds the permitted use, you will need to obtain permission directly from the copyright holder. To view a copy of this licence, visit http://creativecommons .org/licenses/by/4.0/.

\section{References}

1. Misra NN, Tiwari BK (2014) Biscuits. In: Hui YH (ed) Zhou W. Bakery products science and technology, Wiley Blackwell Oxford, pp 585-601

2. Zhang Y, Guo X, Shi C, Ren C (2020) Effect of soy proteins on characteristics of dough and gluten. Food Chem 318:126494. https://doi.org/10.1016/j.foodchem.2020.126494

3. O'Bryan T, Ford R, Kupper C (2012) Celiac disease and nonceliac gluten sensitivity. In: Kohlstadt I (ed) Advancing medicine with food and nutrients, CRC Press, pp 305-330

4. Foschia M, Horstmann S, Arendt EK, Zannini E (2016) Nutritional therapy-facing the gap between coeliac disease and gluten-free food. Int J Food Microbiol 239:113-124. https:// doi.org/10.1016/j.ijfoodmicro.2016.06.014

5. Pietzak MM, Fasano A (2005) Celiac disease: a new paradigm of an immune-mediated disorder due to dietary gluten. In: Watson RR, Preedy VR (eds) Reviews in food and nutrition toxicity. CRC Press, pp 243-265

6. Arslan M, Rakha A, Xiaobo Z, Mahmood MA (2019) Complimenting gluten free bakery products with dietary fiber: opportunities and constraints. Trends Food Sci Technol 83:194-202. https://doi.org/10.1016/j.tifs.2018.11.011

7. Calvo-Lerma J, Crespo-Escobar P, Martinez-Barona S, FornesFerrer V, Donat E, Ribes-Koninckx C (2019) Differences in the macronutrient and dietary fibre profile of gluten-free products as compared to their gluten-containing counterparts. Eur J Clin Nutr 73:930-936. https://doi.org/10.1038/s4143 0-018-0385-6

8. Camire ME (2001) Extrusion and nutritional quality. In: Guy R (ed) Extrusion cooking: technologies and applications. CRC Press, Flórida, pp 108-129

9. Rosell CM, Gómez M (2014) Rice. In: Zhou W, Hui YH (eds) Bakery products science and technology. Wiley Blackwell, Oxford, pp 89-106

10. Rybicka I, Gliszczyńska-Świgło A (2017) Minerals in grain glutenfree products. The content of calcium, potassium, magnesium, sodium, copper, iron, manganese, and zinc. J Food Compos Anal 59:61-67. https://doi.org/10.1016/j.jfca.2017.02.006

11. SIDRA (Sistema IBGE de Recuperação Automática), Levantamento Sistemático da Produção Agrícola, https://sidra.ibge. gov.br/home/lspa/brasil. Accessed 26 June 2020

12. Chau CF, Huang YL (2003) Comparison of the chemical composition and physicochemical properties of different fibers prepared from the peel of Citrus sinensis L. Cv Liucheng. J Agric Food Chem 51:2615-2618. https://doi.org/10.1021/jf025919b

13. Djilas S, Čanadanović-Brunet J, Ćetković G (2009) By-products of fruits processing as a source of phytochemicals. Chem Ind Chem Eng Q 15:191-202. https://doi.org/10.2298/CICEQ0904191D

14. Grasso $S$ (2020) Extruded snacks from industrial by-products: a review. Trends Food Sci Technol 99:284-294. https://doi. org/10.1016/j.tifs.2020.03.012

15. Sharoba AM, Farrag MA, Abd El-Salam AM (2013) Utilization of some fruits and vegetables waste as a source of dietary fiber and its effect on the cake making and its quality attributes. $J$ Agroaliment Process Technol 19:429-444 
16. Shih MC, Hwang TS, Chou HY (2016) Physicochemical and functional property changes in soy protein isolates stored under high relative humidity and temperature. J Food Sci Technol Mys 53:902-908. https://doi.org/10.1007/s13197-015-2057-z

17. Huang YA, Ma YS (2016) The effect of extrusion on the physiochemical properties of extruded orange pomace. Food Chem 192:363-369. https://doi.org/10.1016/j.foodchem.2015.07.039

18. Ng M, Chaya C, Hort J (2013) Beyond liking: comparing the measurement of emotional response using EsSense profile and consumer defined check-all-that-apply methodologies. Food Qual Prefer 28:193-205. https://doi.org/10.1016/j.foodq ual.2012.08.012

19. AACC (American Association of Cereal Chemists) Approved Methods of Analysis, 11 th Ed. Method 44-16.01. Moisture-AirOven (Aluminum-Plate) Method. Approved November 3, 1999. Cereals \& Grains Association, St. Paul, MN, USA. https://doi. org/10.1094/AACCIntMethod-44-16.01

20. Becker A, Hill SE, Mitchell JR (2001) Milling-a further parameter affecting the Rapid Visco Analyser (RVA) profile. Cereal Chem 78:166-172. https://doi.org/10.1094/CCHEM .2001.78.2.166

21. Anderson RA, Conway HF, Pfeifer VF, Griffin EL (1969) Gelatinization of corn grits by roll and extrusion cooking. Cereal Sci Today 14:4-7

22. AACC (American Association of Cereal Chemists) Approved Methods of Analysis, 11th Ed. Method 76-21.01. General Pasting Method for Wheat or Rye Flour or Starch Using the Rapid Visco Analyser. Approved November 3, 1999. Cereals \& Grains Association, St. Paul, MN, USA. https://doi.org/10.1094/AACCI ntMethod-76-21.01

23. Ostermann-Porcel MV, Quiroga-Panelo N, Rinaldoni AN, Campderrós ME (2017) Incorporation of Okara into glutenfree cookies with high quality and nutritional value. J Food Qual. https://doi.org/10.1155/2017/4071585

24. AOAC (2005) Official methods of analysis of the association analytical chemists. AOAC International, Maryland

25. Downes FP, Ito K (2001) Compendium of methods for the microbiological examination of foods. American Public Health Association, Washington DC

26. Brazil (2001) Regulamento técnico sobre padrões microbiológicos para alimentos, Agência Nacional de Vigilância Sanitária, Resolução RDC 12 02/01/2001, Diário Oficial da União, Brasília

27. Macfie HJ, Bratchell N, Greenhoff K, Vallis LV (1989) Designs to balance the effect of order of presentation and first-order carry-over effects in hall tests. J Sens Stud 4:129-148. https:// doi.org/10.1111/j.1745-459X.1989.tb00463.x

28. Hough G, Wakeling I, Mucci A, Chambers E, Gallardo IM, Alves LR (2006) Number of consumers necessary for sensory acceptability tests. Food Qual Prefer 17:522-526. https://doi. org/10.1016/j.foodqual.2005.07.002

29. Næs T, Brockhoff PB, Tomic O (2010) Statistics for sensory and consumer science. Wiley, West Sussex

30. Kemp SE, Hollowood T, Hort J (2009) Sensory test methods. In: Kemp SE, Hollowood T, Hort J (eds) Sensory evaluation-a practical handbook. Wiley Blackwell, West Sussex, pp 66-137

31. Rashid S, Rakha A, Anjum FM, Ahmed W, Sohail M (2015) Effects of extrusion cooking on the dietary fibre content and Water Solubility Index of wheat bran extrudates. Int J Food Sci Technol 50:1533-1537. https://doi.org/10.1111/ijfs.12798

32. Hagenimana A, Ding $X$, Fang $T$ (2006) Evaluation of rice flour modified by extrusion cooking. J Cereal Sci 43:38-46. https:// doi.org/10.1016/j.jcs.2005.09.003

33. Sarawong C, Schoenlechner R, Sekiguchi K, Berghofer E, $\mathrm{Ng}$ PKW (2014) Effect of extrusion cooking on the physicochemical properties, resistant starch, phenolic content and antioxidant capacities of green banana flour. Food Chem 143:33-39. https://doi.org/10.1016/j.foodchem.2013.07.081

34. Altan A, McCarthy KL, Maskan M (2008) Twin-screw extrusion of barley-grape pomace blends: extrudate characteristics and determination of optimum processing conditions. J Food Eng 89:24-32. https://doi.org/10.1016/j.jfoodeng.2008.03.025

35. Cortez RON, Gómez-Aldapa CA, Aguilar-Palazuelos E, DelgadoLicon E, Rosas JC, Hernández-Ávila J, Solís-Soto A, Ochoa-Martínez LA, Medrano-Roldán H (2016) Blue corn (Zea mays L.) with added orange (Citrus sinensis) fruit bagasse: novel ingredients for extruded snacks. Cyta-J Food 14:349-358. https:// doi.org/10.1080/19476337.2015.1114026

36. Carvalho CWP, Takeiti CY, Onwulata CI, Pordesimo LO (2010) Relative effect of particle size on the physical properties of corn meal extrudates: effect of particle size on the extrusion of corn meal. J Food Eng 98:103-109. https://doi.org/10.1016/j. jfoodeng.2009.12.015

37. Ragaee S, Abdel-Aal ESM (2006) Pasting properties of starch and protein in selected cereals and quality of their food products. Food Chem 95:9-18. https://doi.org/10.1016/j.foodc hem.2004.12.012

38. Kim CS, Walker CE (1992) Changes in starch pasting properties due to sugars and emulsifiers as determined by viscosity measurements. J Food Sci 57:1009-1013

39. Wu K, Gan R, Dai S, Cai YZ, Corke H, Zhu F (2016) Buckwheat and millet affect thermal, rheological, and gelling properties of wheat flour. J Food Sci 81:627-636. https://doi. org/10.1111/1750-3841.13240

40. FAO/WHO (Food and Agriculture Organization of the United Nations/World Health Organization), CODEX Alimentarius Guidelines for use of nutrition and health claims (CAC/GL 23-1997), https://www.fao.org/ag/humannutrition/32444 -09f5545b8abe9a0c3baf01a4502ac36e4.pdf. Accessed 26 June 2020

41. Nagarajaiah SB, Prakash J (2016) Chemical composition and bioactivity of pomace from selected fruits. Int J Fruit Sci 16:423-443. https://doi.org/10.1080/15538362.2016.1143433

42. Huang YA, Ma YS, Tsai YH, Chang SKC (2019) In vitro hypoglycemic, cholesterol-lowering and fermentation capacities of fiber-rich orange pomace as affected by extrusion. Int J Biol Macromol 124:796-801. https://doi.org/10.1016/j.ijbio mac.2018.11.249

43. Arribas C, Cabellos B, Guillamón E, Martin PM (2020) Cooking and sensorial quality, nutritional composition and functional properties of cold-extruded rice/white bean gluten-free fettuccine fortified with whole carob fruit flour. Food Funct 11:7913-7924. https://doi.org/10.1039/D0FO01470B

44. Morales P, Cebadera-Miranda L, Cámara RM, Reis FS, Barros L, Berrios JDJ, Ferreira ICFR, Cámara M (2015) Lentil flour formulations to develop new snack-type products by extrusion processing: phytochemicals and antioxidant capacity. J Funct Foods 19:537-544. https://doi.org/10.1016/j.jff.2015.09.044

45. Brazil, (2005) Regulamento técnico sobre a ingestão diária recomendada (IDR) de proteína, vitaminas e minerais, Agência Nacional de Vigilância Sanitária, Resolução RDC 269 22/09/2005. Diário Oficial da União, Brasília

46. WHO (World Health Organization) (2012) Guideline: potassium intake for adults and children. WHO, Geneva

47. Gava AJ (2010) Microbiologia de Alimentos - Fatores que afetam a multiplicação dos microrganismos. In: Gava AJ (ed) Tecnologia de alimentos: princípios e aplicações. Nobel, São Paulo, pp 93-105

48. Fellows PJ (2017) Properties of food and principles of processing. In: Fellows PJ (ed) Food processing technology: principles and practice. CRC Press LLC, Boca Raton, pp 3-200 
49. Oh IK, Bae IY, Lee HG (2014) In vitro starch digestion and cake quality: Impact of the ratio of soluble and insoluble dietary fiber. Int J Biol Macromol 63:98-103. https://doi.org/10.1016/j. ijbiomac.2013.10.038

50. Kiharason JW, Isutsa DK (2019) Shelf-life of pumpkin fruit slices, flour and blended products. Int J Food Sci Biotechnol 4:14-25. https://doi.org/10.11648/j.ijfsb.20190401.13

51. Santos AAO, Santos AJAO, Silva ICV, Leite MLC, Soares SM, Marcellini OS (2010) Desenvolvimento de biscoitos de chocolate a partir da incorporação de fécula de mandioca e albedo de laranja. Alim Nutr Araraquara 21:469-480

52. Santos AAO, Silva IVC, Santos JPA, Santana DG, Almeida ML, Marcellini PS (2011) Elaboração de biscoitos de chocolate com substituição parcial da farinha de trigo por polvilho azedo e farinha de albedo de laranja. Cienc Rural 41:531-536
53. Seo HS, Adams SH, Howard LR, Brownmiller C, Hogan V, Chen JR, Pramudya RC (2020) Children's liking and wanting of foods vary over multiple bites/sips of consumption: a case study of foods containing wild blueberry powder in the amounts targeted to deliver bioactive phytonutrients for children. Food Res Int 131:108981. https://doi.org/10.1016/j.foodr es.2020.108981

Publisher's Note Springer Nature remains neutral with regard to jurisdictional claims in published maps and institutional affiliations. 